\title{
Pendampingan Kewirausahaan bagi Usaha Mikro, Kecil dan Menengah di Kecamatan Ciledug Kota Tangerang
}

\author{
Slamet Mudjijah1, Triana Anggraini2 \\ 1,2Universitas Budi Luhur \\ e-mail: ${ }^{1}$ slamet.mudjijah@budiluhur.ac.id, 2triana.anggraini@budiluhur.ac.id
}

\begin{abstract}
Abstrak
Mitra dalam program pengabdian masyarakat ini adalah Pelaku Usaha Mikro Kecil dan Menengah (UMKM) terutama usaha pemula di Kecamatan Ciledug, Kota Tangerang. Permasalahan yang dihadapi oleh UMKM pemula apalagi yang baru beberapa bulan merintis usaha adalah sangat mudah goyah keberlanjutan usahanya, pengelolaan keuangan belum professional, pelaku UMKM belum sepenuhnya memahami pasar untuk produknya, kemasan masih dibuat secara sederhana. Permasalahan semakin mengkhawatirkan setelah adanya pandemi Covid 19. Sebagian besar pelanggan yang sudah mulai rutin mengkonsumsi produk UMKM menjadi terhenti sehingga penjualan menurun drastis. Solusi atas permasalahan tersebut adalah dilakukan analisis ulang kelayakan usaha dengan mengenali customer base dan kebutuhannya, mempermudah proses bisnis, mengklasifikasi produk yang mudah dijual. Metode yang digunakan dalam kegiatan ini adalah observasi secara langsung dengan Pengurus UMKM Kecamatan Ciledug. Kegiatan dilanjutkan dengan pertemuan dalam bentuk pendampingan. Kegiatan pengabdian kepada pelaku UMKM di Kecamatan Ciledug Kota Tangerang ini telah dilakukan dengan hasil sebagai berikut: peserta semakin mampu mengidentifikasi permasalahan bisnis terutama pada penetapan harga dan kualitas produk, peserta telah memiliki pengetahuan untuk menganalisis kelayakan bisnisnya terutama pada aspek pasar dan legalitas, motivasi peserta semakin meningkat dengan adanya jaringan dalam penjualan produk terutama penjualan langsung maupun reseller, pemanfaatan gerai Pojok UMKM Ciledug semakin optimal, koordinator UMKM semakin termotivasi untuk memajukan pelaku UMKM terutama dalam peningkatan kesadaran terhadap legalitas usaha.
\end{abstract}

\section{Kata Kunci: pendampingan, kewirausahaan, UMKM}

\section{Abstract}

Partners in this community service program are Micro, Small and Medium Enterprises (MSMEs) especially novice businesses in Ciledug Subdistrict, Tangerang City. The problem faced by novice MSMEs especially those who have only been established for a few months, is that their business continuity is easily faltering, financial management is not yet professional, MSMEs have not fully understood the market for their products, packaging is still made simply. The problem is increasingly worrying after the Covid 19 pandemic. Most customers who have started to routinely consume MSME products become stopped so that sales decrease drastically. The solution to the problem is to re-analyze the feasibility of the business by 
recognizing the customer base and its needs, simplifying business processes, classifying products that are easy to sell. The method used in this activity is direct observation with the MSME Board of Ciledug Sub-District. The activity was continued with a meeting in the form of mentoring. This service activity to MSMEs in Ciledug District of Tangerang City has been carried out with the following results: participants are increasingly able to identify business problems, especially on pricing and product quality, participants have the knowledge to analyze their business feasibility, especially in the market aspect and legality, the motivation of participants is increasing with the network in product sales, especially custumer and reseller, the utilization of Ciledug MSME Corner outlets is increasingly optimal, MSME coordinators are increasingly motivated to advance MSMEs, especially in raising awareness of business legality.

\section{Keyword: Mentoring, enterpreneurship, MSME}

\section{Pendahuluan}

Pada krisis ekonomi tahun 1998 dan 2008, sektor UMKM memang menjadi penopang ekonomi karena mayoritas belum mendapat akses finansial dan permodalan sehingga tidak terdampak krisis. Namun ketahanan tersebut tidak berlaku saat ini, sektor UMKM justru paling rentan atas imbas virus corona. Masyarakat berada dalam kondisi waspada dan sangat berhati-hati dengan membatasi bepergian dan konsumsi, tentunya hal ini berimbas kepada transaksi jual beli. Usaha Kecil dan Menengah pemula sangat terdampak terhadap kondisi wabah virus corona 19 yang terjadi saat ini. UMKM pemula apalagi yang baru merintis usaha sangat mudah goyah keberlanjutan usahanya bahkan akan kehilangan pasar sama sekali. Berdasarkan hasil wawancara langsung yang dilakukan pada awal maret 2020 (sesaat sebelum virus corona mewabah terutama di Jakarta) dengan pengurus UMKM Kecamatan Ciledug, setiap bulan terdapat 15 pelaku UMKM baru yang sebagian besar menekuni bidang makanan dan minuman. Pelaku UMKM pemula di Kecamatan Ciledug mayoritas ibu rumah tangga yang berkeinginan membantu keuangan keluarga. Usaha yang telah dijalankan beberapa bulan sebelumnya mulai menunjukkan hasil bagi pelaku UMKM pemula antara lain berupa: keuntungan usaha dan mulai memiliki pelanggan tetap. Bahkan UMKM ini telah mendapatkan berbagai pelatihan entrepreneurship dan e-comerce. Namun berdasarkan wawancara lanjutan dengan Koordinator UMKM melalui media telepon, UMKM pemula di Kecamatan Ciledug pada masa pandemi covid 19 saat ini mulai mengalami kesulitan dalam melanjutkan usahanya. Usaha yang telah dirintis mengalami goncangan karena menghadapi beberapa kendala, yaitu:

1. Sebagian besar pelanggan yang sudah mulai rutin mengkonsumsi produk UMKM menjadi terhenti sehingga penjualan menurun drastis.

2. Keuangan bisnis telah tercampur dengan keuangan keluarga akibat krisis pemasukan utama.

3. Pembuatan kemasan dan pengajuan merek yang telah diawali beberapa bulan sebelumnya tidak berlanjut karena bantuan pendampingan ahli terhenti.

4. Proses produksi mengalami kendala dalam penyediaan bahan baku. 
Dampak dari seluruh kendala yang dihadapi mengakibatkan hilangnya motivasi berwirausaha yang telah terbangun.

Keberlanjutan UKM pemula di Kecamatan Ciledug menjadi prioritas penting yang perlu diselamatkan saat ini, sehingga tetap dapat berproduksi dan beraktivitas bisnis kembali. Pelaku UKM pemula harus dapat bertahan walaupun pada masa pandemi Covid 19 saat ini sehingga dapat berkontribusi pada perekonomian keluarga khususnya dan perkekonomian masyarakat Kecamatan Ciledug pada umumnya. UMKM perlu melakukan penyesuaian proses bisnis agar cash flow tetap positif yaitu dengan analisis kelayakan bisnis. Analisis kelayakan bisnis secara komprehensif mencakup aspek pemasaran, legalitas, produksi, keuangan dan lingkungan (Anam 2017). Kegiatan ini bertujuan membantu UMKM Pemula dalam menganalisis ulang aspek kelayakan bisnis antara lain dengan cara mengevaluasi pengelolaan keuangan, mengenali customer base dan kebutuhannya, mempermudah proses bisnis, mengklasifikasi produk yang mudah dijual.

Proses analisis kelayakan usaha pada umumnya dilakukan oleh pelaku bisnis atau dengan bantuan ahli (Sobana 2018). Pelaku UMKM di Kecamatan Ciledug membutuhkan bantuan dari pihak terkait untuk melakukan analisis usaha agar bisnis dapat diselamatkan. Dinas Koperasi dan UKM Kota Tangerang memiliki tanggung jawab untuk segera menindaklanjuti program Pemerintah Pusat dalam penyelamatan UKM di tengah pendemi virus corona saat ini. Namun tentu saja pemerintah memiliki keterbatasan dalam menyentuh pelaku UKM pemula yang berada di tingkat kecamatan, termasuk Kecamatan Ciledug. Universitas Budi Luhur khususnya Fakultas Ekonomi dan Bisnis sebagai bagian dari unsur triple helix berperan sebagai pihak akademis yang memiliki tanggung jawab untuk ikut berperan serta dalam upaya penyelamatan UKM pemula di wilayah Kecamatan Ciledug.

Analisis kelayakan bisnis adalah suatu kegiatan identifikasi dan merencanakan serta memperdalam seluruh aktivitas dan usaha untuk mencari keuntungan maupun sosial dengan menyediakan barang dan jasa yang dibutuhkan bagi sistem perekonomian, dengan output berupa keputusan penentuan layak atau tidak layak suatu usaha dijalankan. (Purnomo, 2017:9)

Suliyanto (2010:9) menjelaskan bahwa untuk memperoleh kesimpulan yang kuat tentang dijalankan atau tidaknya sebuah ide bisnis, studi kelayakan bisnis yang mendalam perlu dilakukan pada beberapa aspek kelayakan bisnis, yaitu:

1. Aspek Hukum menganalisis kemampuan pelaku bisnis dalam memenuhi ketentuan hukum dan perijinan yang diperlukan untuk menjalankan bisnis di wilayah tertentu.

2. Aspek lingkungan menganalisis kesesuaian lingkungan sekitar (baik lingkungan operasional, lingkungan dekat, dan lingkungan jauh) dengan ide bisnis yang akan dijalankan. Dalam aspek ini dampak bisnis bagi lingkungan juga dianalisis.

3. Aspek Pasar menganalisis potensi pasar, intensitas persaiangan, market share yang dapat dicapai, serta menganalisis strategi pemasaran yang dapat digunakan untuk mencapai market share yang diharapkan. 
4. Aspek Tekhis menganalisis kesiapan teknis dan ketersediaan teknologi yang dibutuhkan untuk menjalankan bisnis.

5. Aspek Manajemen dan Sumber Daya Manusia menganalisis tahap - tahap pelaksanaan bisnis dan kesiapan tenaga kerja, baik tenaga kerja kasar maupun tenaga kerja terampil yang diperlukan untuk menjalankan bisnis.

6. Aspek Keuangan menganalisis besarnya biaya investasi dan modal kerja serta tingkat pengembalian investasi dan bisnis yang akan dijalankan.

Menurut Kasmir dan Jakfar (2006:88) ada lima tujuan mengapa sebelum suatu usaha atau proyek dijalankan perlu dilakukan studi kelayakan yaitu :

1. Menghindari resiko kerugian

Resiko kerugian untuk masa yang akan datang yang penuh dengan ketidak pastian, dalam hal ini fungsi studi kelayakan untuk meminimalkan resiko baik yang dapat dikendalikan maupun yang tidak dapat dikendalikan.

2. Memudahkan Perencanaan

Perencanaan meliputi berapa jumlah dana yang diperlukan, kapan usaha akan dijalankan, dimana, bagaimana pelaksanaannya, berapa besar keuntungan yang akan diperoleh serta bagaimana mengawasinya jika terjadi penyimpangan.

3. Memudahkan Pelaksanaan Pekerjaan

Dengan rencana yang telah tersusun maka sangat memudahkan pelaksanaan bisnis, pengerjaan usaha dapat dilakukan secara sistematik.

4. Memudahkan Pengawasan

Dengan melaksanakan proyek sesuai rencana maka memudahkan untuk melakukan pengawasan terhadap jalannya usaha.

5. Memudahkan Pengendalian

Jika dapat diawasi maka jika terjadi penyimpanganakan muidah terdeteksi, sehingga mudah untuk mengendalikan penyimpangan tersebut.

Menurut Umar (2005:21) dalam melaksanakan studi kelayakan bisnis, ada beberapa tahapan studi yang hendaknya dikerjakan, yaitu:

1. Penemuan Ide

Produk yang akan dibuat haruslah berpotensi untuk laku dijual dan menguntungkan. Oleh karena itu, penelitian terhadap kebutuhan pasar dan jenis produk atau proyek harus dilakukan. Untuk menghasilkan ide suatu proyek, perlu dilakukan penelitian yang terorganisasi dengan baik serta dukungan sumber daya yang memadai.

2. Tahap Penelitian

Dimulai dengan mengumpulkan data, lalu mengolah data berdasarkan teoriteori yang releven, menganalisis dan menginterprestasikan hasil pengolahan data dengan alat-alat analisis yang sesuai, menyimpulkan hasil sampai pada pekerjaan membuat laporan hasil penelitian tersebut.

3. Tahap Evaluasi

Evaluasi berarti membandingkan sesuat dengan satu atau lebih standar atau kriteria, dimana standar atau kriteria ini dapat bersifat kuantitatif maupun 
kualitatif. Hal yang dibandingkan dalam evaluasi bisnis adalah ongkos yang akan ditimbulkan oleh usulan bisnis serta manfaat atau benefit yang diperkirakan akan diperoleh.

\section{Metode}

Kegiatan pengabdian kepada masyarakat ini merupakan kegiatan pendampingan oleh tim dosen Universitas Budi Luhur pada pelaku UMKM di wilayah Kecamatan Ciledug. Pendampingan bagi para pelaku UMKM ini juga melibatkan mahasiswa ditujukan untuk meningkatkan kepedulian mahasiswa pada persoalan-persoalan yang terjadi di tengah masyarakat.

Kegiatan diawali dengan observasi secara langsung dengan Pengurus UMKM yang ditunjuk oleh Kecamatan Ciledug. Kegiatan dilanjutkan dengan pendampingan.

1. Observasi

Kegiatan observasi telah dilakukan dengan diskusi dengan Koordinator UMKM pada awal bulan Maret 2020 di Kantor Kecamatan Ciledug. Kegiatan observasi dilanjutkan dengan berkomunikasi langsung pada awal bulan April dengan media telepon. Berdasarkan observasi, telah diperoleh informasi tentang kendala-kendala yang dihadapi oleh Usaha Kecil dan Menengah di Kecamatan Ciledug, Kota Tangerang. Setelah didiskusikan dengan Koordinator UMKM Kecamatan Ciledug, maka diputuskan kegiatan pengabdian masyarakat yang dilakukan segera adalah melakukan pendampingan kepada pelaku UMKM pemula untuk membangkitkan motivasi berwirausaha dalam menghadapi pandemic Covid 19. Materi yang diberikan adalah menganalisis kembali kelayakan bisnis sehingga diharapkan dapat melakukan produksi kembali.

2. Pendampingan

Kegiatan pendampingan dilakukan pada bulan September 2020, bertempat di lokasi gerai Pojok UMKM Kecamatan Ciledug Kota Tangerang. Metode pendampingan yang digunakan dalam kegiatan pengabdian masyarakat ini adalah pendampingan langsung pada tiap peserta kegiatan. Metode pendampingan secara langsung pada setiap pelaku UMKM dipertimbangkan sebagai metode yang paling tepat pada saat pemberlakuan PSBB di Kota Tangerang saat ini. Pendampingan dilakukan langsung dengan memperhatikan penggunaan masker dan menjaga jarak aman. Peserta dibagi dalam beberapa kelompok kecil. Setiap kelompok diberikan pengarahan tentang materi kelayakan bisnis dan berdiskusi mengenai kasus usaha masing-masing.

\section{Hasil dan Pembahasan}

Kegiatan Pengabdian Kepada Masyarakat dengan tema pendampingan analisis kelayakan bisnis bagi Usaha Kecil dan Menengah Pemula Di Kecamatan Ciledug, Kota Tangerang telah dilaksanakan. Kegiatan diawali dengan pengenalan dan pemahaman kelayakan suatu usaha kepada para pelaku UMKM yang menitikberatkan pada pentingnya strategi agar usaha tetap bisa bertahan dalam kondisi pandemi covid saat ini. Pelaksanaan kegiatan meliputi pendampingan 
langsung dilanjutkan dengan diskusi. Peserta pelatihan adalah pelaku UMKM Pemula di wilayah Kecamatan Ciledug, Tangerang.

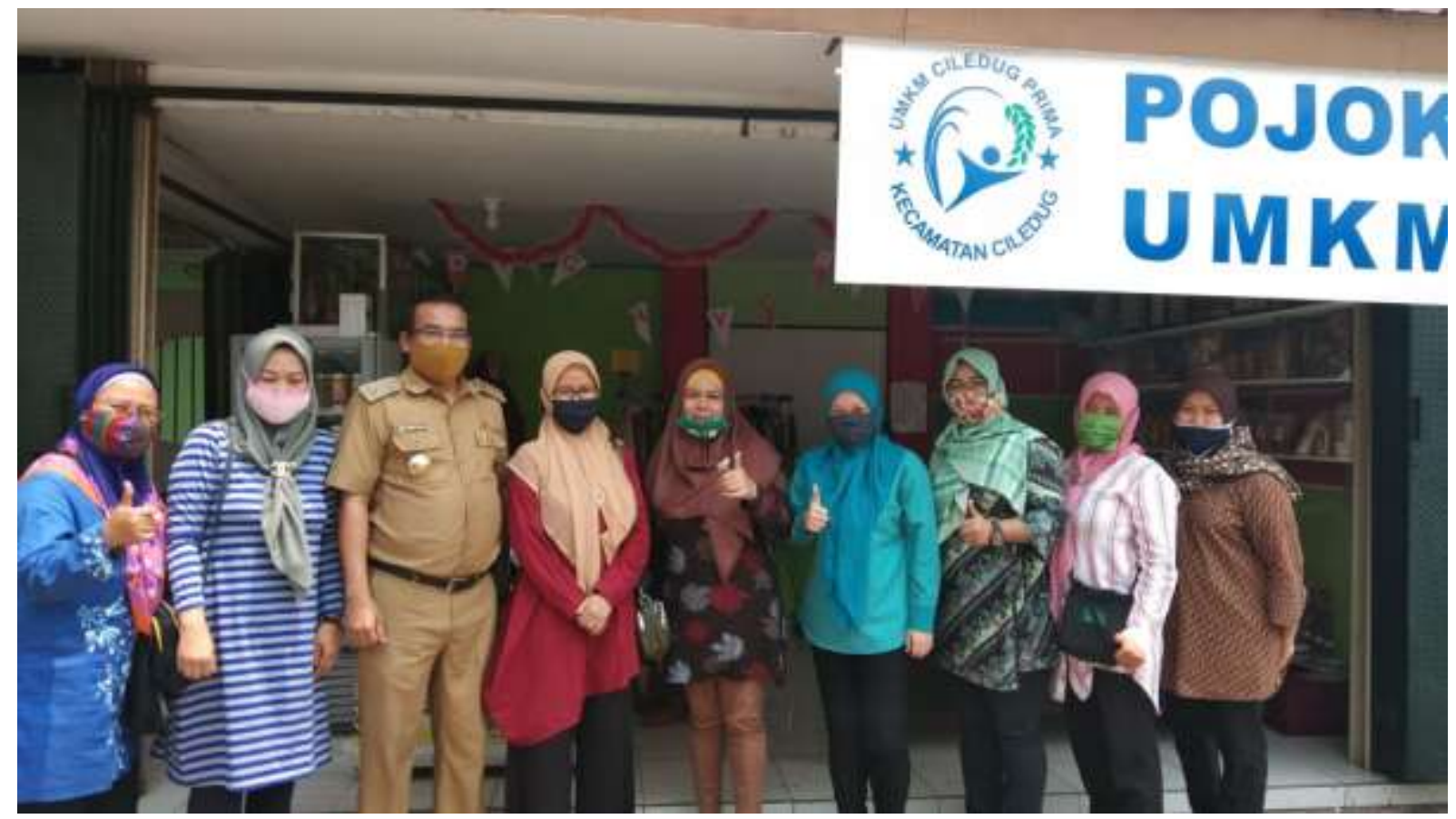

Gambar 1. Situasi Pendampingan Analisis Kelayakan Bisnis

Setelah dilakukan pendampingan langsung dengan pelaku UMKM dengan lokasi pertemuan di gerai Pojok UMKM Kecamatan Ciledug, terdapat informasi bahwa:

1. Metode pemasaran yang dilakukan sebagian besar masih cenderung tradisional yaitu melalui word of mouth dan penawaran langsung ke konsumen, meskipun sebagian sudah mulai memanfaatkan penjualan melalui sosial media. Pada akhir tahun 2019, telah dilakukan pelatihan tentang penjualan melalui e-commerce. Pelaku UMKM di wilayah Ciledug diharapkan bisa memperluas jaringan pemasaran dan memperkenalkan produknya dengan lebih baik. Pelatihan $e$ commerce belum diterapkan secara optimal oleh peserta dalam kegiatan berbisnis. Keadaan ini disebabkan kurangnya kemampuan para pelaku UMKM di Ciledug dalam pemanfaatan TIK.

2. Produk yang dijual di gerai Pojok UMKM Kecamatan Ciledug telah ditata dengan menarik, namun setelah dilakukan pengecekan rasa terdapat beberapa produk makanan yang sudah tidak fresh lagi. Harga yang ditetapkan terjangkau namun terdapat produk relatif lebih mahal dibanding produk sejenis yang dijual secara online. Meskipun hanya beberapa produk yang dijual lebih mahal, akan mempengaruhi kesan pembeli terhadap harga keseluruhan produk yang dijual. Permasalahan tersebut dapat mempengaruhi kepercayaan pembeli sehingga tidak akan melakukan pembelian kembali. 


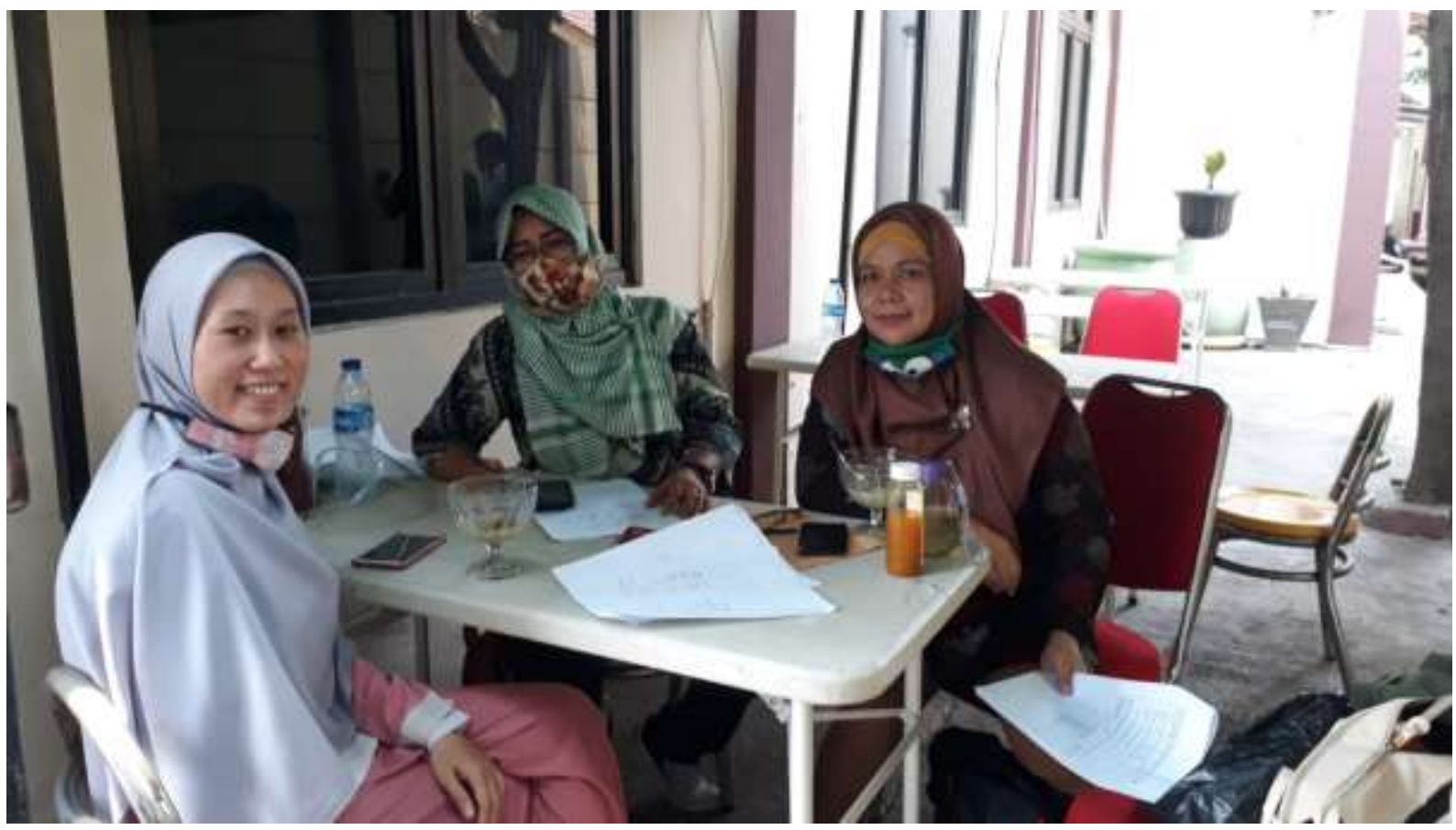

Gambar 2. Suasana diskusi Analisis Kelayakan Bisnis

Berdasarkan kegiatan pendampingan dan diskusi dengan para peserta pada kegiatan pengabdian masyarakat yang diselenggarakan di Kantor Kecamatan Ciledug, diperoleh informasi sebagai berikut:

1. Mayoritas pelaku UMKM di Kecamatan Ciledug masih tergolong dalam kategori usaha mikro yang bergerak di berbagai bidang seperti:

a. Makanan dan minuman (makanan ringan \& makanan berat)

b. Kerajinan

c. Fashion

Berdasarkan permasalahan yang telah dikemukakan sebelumnya pada bab ini, penetapan harga akan dievaluasi kembali dengan memperhatikan harga kompetitor. Kualitas produk terutama tingkat kesegaran makanan akan lebih diperhatikan

2. Metode pemasaran yang dilakukan sebagian besar masih cenderung tradisional yaitu melalui word of mouth dan penawaran langsung ke konsumen, namun sebagian sudah mulai memanfaatkan penjualan melalui sosial media. Koordinator UMKM difasilitasi oleh pejabat kantor Kecamatan Ciledug telah berhasil membangun gerai yang dinamakan "Pojok UKM" untuk memasarkan produk UMKM binaan. Gerai ini sangat membantu pelaku UMKM dalam memasarkan produknya setelah mengalami krisis selama masa pandemi virus corona. Pelaku UMKM menghendaki untuk mendapatkan pelatihan lanjutan tentang pemanfaatan TIK agar dapat diaplikasikan dalam penjualan berbasis online.

3. Legalitas usaha belum dimiliki sebagian besar pelaku UMKM di Kecamatan Ciledug, sehingga pada kegiatan ini ditekankan manfaat legalitas usaha seperti pengurusan perijinan. Pelaku UMKM belum sepenuhnya menyadari manfaat ijin usaha. Pemerintah melalui Kantor Kecamatan telah berupaya untuk mempermudah proses pengajuan ijin usaha. Pengurusan perijinan usaha saat ini 
gratis dan menggunakan media online. Namun nampaknya media online menjadi kendala karena pengetahuan para pelaku UMKM di Ciledug terhadap pemanfaatan teknologi informasi masih kurang.

4. Dalam kegiatan PKM ini, pengemasan produk yang dijual sudah menarik lengkap dengan label dan materi kemasan yang aman. Namun untuk produk yang sudah mulai dikenal diarahkan untuk mengajukan hak atas merek dagang. Selanjutnya produk-produk tersebut didiskusikan, dimulai dari manfaat dan proses pengajuan hak atas merek dagang. Pembinaan tentang merek dagang sudah pernah diberikan, namun belum diimplementasikan oleh pelaku UMKM di Kecamatan Ciledug.

5. Permasalahan pelaku UMKM dalam mengelola keuangan adalah mencampuradukkan kuuangan usaha dengan keuangan pribadi. Pelaku UMKM semakin mengalami kesulitan dalam mengelola keuangan usaha setelah terkena imbas pandemi virus corona. Keuangan usaha telah digunakan untuk memenuhi kebutuhan sehari-hari. Pelaku UMKM diarahkan untuk melakukan pencatatan kas masuk dan kas keluar.

6. Berdasarkan hasil diskusi dengan pelaku dan koordinator UMKM, selanjutnya tim dosen diharapkan menyelenggarakan kegiatan lanjutan bagi para pelaku UMKM di Kecamatan Ciledug. Materi pembinaan yang masih perlu diberikan adalah terkait dengan pemanfaatan TIK dalam operasi bisnis, perijinan usaha dan perolehan hak atas merek dagang.

\section{Simpulan dan Rekomendasi}

Kegiatan pengabdian kepada pelaku UMKM di Kecamatan Ciledug Kota Tangerang ini telah dilakukan dan dapat disimpulkan sebagai berikut: peserta telah mampu mengidentifikasi permasalahan bisnis terutama pada penetapan harga dan kualitas produk, Peserta telah memiliki pengetahuan untuk menganalisis kelayakan bisnisnya terutama pada aspek pasar dan legalitas. Motivasi peserta semakin meningkat dengan adanya jaringan dalam penjualan produk terutama penjualan langsung maupun reseller. Pemanfaatan gerai Pojok UMKM Ciledug semakin optimal. Koordinator UMKM semakin termotivasi untuk memajukan pelaku UMKM terutama dalam peningkatan kesadaran terhadap legalitas usaha.

Berdasarkan hasil diskusi dengan peserta kegiatan pendampingan ini, maka sebaiknya perlu diberikan beberapa rekomendasi. Pelaku UMKM perlu membangun kembali motivasi dalam menjalankan bisnisnya dan langkah-langkah yang sebaiknya dilakukan antara lain secara aktif membangun jaringan usaha serta mengikuti kegiatan pembinaan yang diselenggarakan oleh Komunitas UMKM di Kantor Kecamatan Ciledug. Pelaksana pendampingan perlu memantau perkembangan usaha para peserta agar dapat mengevaluasi kembali keberhasilan kegiatan pendampingan. Penyelenggara pembinaan sebaiknya melanjutkan kegiatan pengabdian dengan pendampingan usaha khususnya berkaitan dengan peningkatan kemampuan TIK serta pengajuan perijinan dan merek dagang. 


\section{Acknowledgements}

Tim Penulis mengucapkan banyak terima kasih kepada Universitas Budi Luhur yang telah memberikan fasilitas berupa dana kegiatan dan kerjasama dengan Kantor Kecamatan Ciledug Kota Tangerang sehingga mempermudah pelaksanaan kegiatan Pengabdian Kepada Masyarakat ini.

\section{Daftar Pustaka}

Anam, Chairul. 2017. Study Kelayakan Bisnis: Teori Dan Aplikasi. Yogyakarta: Deepublish.

Kasmir dan Jakfar. 2006. Studi Kelayakan Bisnis. Jakarta: Prenada Media Group.

Purnomo, Rochmat Aldy, Riawan dan La Ode Sugianto. 2017. Studi Kelayan Bisnis. Ponorogo: Unmuh Ponorogo Press.

Sobana, Dadang Husen. 2018. Studi Kelayakan Bisnis. Bandung: Pustaka Setia.

Suliyanto. 2010. Studi Kelayakan Bisnis, Pendekatan Praktis. Yogyakarta: Penerbit Andi.

Umar, Husein. 2005. Manajemen Riset Dan Perilaku Konsumen. Jakarta: PT. Gramedia Pustaka Utama. 